\title{
ENVIRONMENTAL INTERPRETATION: HERMENEUTIC ANALYSIS OF THE INTERPRETATION OF ANTHROPOCENTRIC VERSES IN AL-QUR'AN
}

\author{
Abdul Fatah and Imam Taufiq \\ Universitas Islam Negeri Walisongo, Semarang \\ alfatahjos@gmail.com \\ Article history:
}

Submitted: 07-12-2018 | Revised: 08-01-2019 | Revised: 22-02-2019 |

Revised: 03-05-2019 | Revised: 24-07-2019 |

Accepted: 23-10-2019

\begin{abstract}
The aim of this study is addressed to environmental problems from the perspective of the Qur'an. The focus of the research is the anthropocentric verses in the Qur'an. Anthropocentric verses are verses that have the meaning of humans as the center of the universe or humans as creatures that are super-being. The categorization of anthropocentric verses is compiled thematically (maudhu' $\hat{\imath}$ ) using a contextual hermeneutic approach. The classification of anthropocentric verses as a result of this research are: 1) Humans as the most glorified creatures 2) Humans as creatures that have power in nature, and 3) Humans as caliphs on earth. Several hermeneutical analyzes of the anthropocentric verse have been obtained. Human must not be arrogant as creatures that degrees are glorified. Humans are instructed not to cause damage on the earth and must be able to do good ihsân to all creatures created by Allah SWT. The obligation of humans as caliphs on earth is to prosper the earth rather than damage the earth.
\end{abstract}

Keywords: Interpretation, Environment, Anthropocentric Verses

\begin{abstract}
Abstrak
Tujuan dari penelitian ini adalah untuk menjawab permasalahan lingkungan dalam perspektif al-Qur'an. Adapun fokus kajiannya adalah ayat-ayat antroposentris dalam al-Qur'an. Ayat antroposentris adalah ayat yang memiliki makna manusia sebagai pusat dari alam semesta atau manusia sebagai makhluk yang paling unggul (super being). Kategorisasi dari ayat antroposentris dihimpun secaara tematik (maudhû'̂̂) dengan pendekakan hermeneutika kontekstual. Adapun hasil dari kajian ini adalah sebagai berikut, kategorisasi ayat-ayat antroposentris adalah: 1) Manusia sebagai makhluk paling dimuliakan, 2) Manusia sebagai makhluk yang memiliki kuasa pada alam, dan 3) Manusia sebagai khalîfah di bumi. Adapun analisis hermeneutis ayat-ayat antroposentris adalah sebagai berikut: Manusia sebagai makhluk yang dimuliakan derajatnya diingatkan untuk tidak sombong. Manusia juga diberi perintah untuk tidak membuat kerusakan di bumi dan harus mampu berbuat baik ihsân pada semua makhluk ciptaan Allah SWT. Manusia mendapatkan mandat sebagai khalîfah di bumi. Manusia diingatkan tugasnya adalah untuk memakmurkan bumi bukan sebaliknya merusak bumi.
\end{abstract}

Kata Kunci: Tafsir, Lingkungan, Ayat-ayat Antroposentris 


\section{Introduction}

The severity of environmental problems today is often marked by ecological disasters such as floods, landslides, drought, pollution, global warming and so on. The utilization of natural resources that arenot compensatedwith adequate conservation is a destructive activity in the environment. This activity is evidenced by many conservation zones or agricultural lands that have been converted into industrial or residential areas. Many deforested forests are felled to meet human needs so that water catchment is getting less and eventually causes floods and landslides. Recorded in Indonesia during 2018, there have been 679 floods, 473 avalanches, and 2,572 natural disasters which caused the death toll of 4,814 people. ${ }^{1}$ These environmental problems are a little example of ecological impacts due to unfriendly human behavior on the environment.

The current environmental crisis that is affecting humanity is caused by behavior and paradigms that are not friendly to the environment as a result of the assumption that the natural world is intended to fulfill human life (anthropocentric views). Several environmentalists support this thesis; Sony Keraf believes that environmental problems are a matter of irresponsible, selfishness and neglect of ecological sustainability. ${ }^{2}$ Human behavior ignoring the environment is illustrated by the many human activities that are not ecologically oriented such as industrial pollution or motor vehicles that cause water and air quality damage. Behavior ignoring the environment causes the level of air pollution in the world to a serious level. The results of a WHO (World Health Organization) study in 2018 showed that 9 out of 10 people in the world breathe air containing high pollutants. ${ }^{3}$

\footnotetext{
${ }^{1}$ See, Indonesian Disaster data and information (Badan Nasional Penanggulangan bencana) http://dibi.bnpb.go.id/.

${ }^{2}$ A. Sony Keraf, Etika Lingkungan Hidup (Jakarta: Kompas, 2010), 1.

${ }^{3}$ World Health Organization, 9 out of 10 People Worldwide Breath Polluted Air, https://www.who.int/news-room/ detail/02-05-2018-9-out-of-10-people-worldwide-
}

According to Suwito NS, the environmental crisis that has occurred so far is due to the absence of human spiritual values. Human nature is the desire and desire for something, while the urge of desire (lust) often leads to damage if it can not be managed properly. As a result of human greed (lust) the environment becomes damaged, the balance of nature is disrupted, and even many species are threatened. ${ }^{4}$ According to Walter Jetz, professor of ecology and biology at the Yale School of Public Health, because of human greed to meet their needs and desires, by 2070, it is predicted that around 1,700 species face the risk of extinction due to increased land use by humans. ${ }^{5}$ Therefore, Assayed Jamil reminded us that today's environmental conditions would not change for the better unless humans change their behavior better in nature. ${ }^{6}$ In general, humans who have a lack of concern for the environment are caused by wrong views which lead to improper conduct as well. One of the contributors to this incorrect way of looking at nature is anthropocentrism ethics. This understanding believes that humans are the center of the universe and only humans who have temporary values of life and everything in it are instruments of satisfying human interests and needs. ${ }^{7}$

Based on the understanding of these experts, it can be concluded that humans are one of the pivots of the presence of environmental damage to overcome ecological problems like build an environmentally oriented paradigm. The efforts can be made through religious

breathe-polluted-air-but-more-countries-are-takingaction, accessed on 20 March 2019.

${ }^{4}$ Suwito, NS, Eko-Sufism Konsep, Strategi, dan Dampak (Yogyakarta: STAIN Press Purwokerto bekerja sama dengan Buku Litera, 2011), 113-114.

${ }^{5}$ Yale News, Due to Humans, Extintion risk for 1,700 animal species to increseangly by 2070. https://news.yale. edu/2019/03/04/due-humans-extinction-risk-1700-animalspecies-increase-2070 accessed on 20 March 2019.

${ }^{6}$ Muhammad Assayed Jamil, A Study on Environmental Issue with Reference to the Qur'an and the sunna, translated by Lachen Haddad (Kingdom of Morocco: Imprimerie Al-Ma'arif Al-Jadida Rabat,1999), 7.

${ }^{7}$ Sony Keraf, Etika Lingkungan Hidup, 2-3. 
media. Remembering religion is one source of human ethics or morals. The reason for belief as a tool to build the perspective of people with environmental insight has been conveyed by Lynn White, JR, an environmentalist from America who said:

"What we do about ecology depends on our ideas of the man-nature relationship. More science and more technology are not going to get us out of the present ecologic crisis until we find a new religion, or rethink our old one." 8

In his statement, explained knowledge and technology would not be able to overcome the ecological crisis/environmental crisis that has and is happening. Religion is a solution to overcome it by interpreting and comprehending religious teachings related to humans and nature.

Abdul Quddus affirmed Lynn White's statement that the environmental crisis occurred was not merely a secular problem, but also a critical religious problem because it began with a wrong understanding of religion about life and the environment. ${ }^{9}$ Victor believed that humans need to ponder how to live the teachings of faith so far as to neglect to pay serious attention to the ecological crisis and environmental destruction. Efforts are required to review the relationship between religion and the environment and the results are then used to solve ecological problems. ${ }^{10}$

Based on the understanding of experts, the role of religion is needed to constructa paradigm on environmental vision. This study examined the interpretation of the anthropocentric verses in the Qur'an, which is the meaning of the verses emphasizes human beings compared

\footnotetext{
${ }^{8}$ Lynn White, JR. "The Historical Roots of Our Ecological Crisis,” Science, New Series 155, no. 3767 (Mar. 10, 1967): 1206.

${ }^{9}$ Abdul Quddus, "Ecotheology Islam: Teologi Konstruktif Atasi Krisis Lingkungan," Jurnal Studi Keislaman Ulumuna 16, no. 2 (Desember 2012): 317.

${ }^{10}$ Victor I. Tanja, "Agama dan Permasalahan Lingkungan", In Sulastomo et.al., Kontekstualisasi Ajaran Islam 70 Tahun Prof. Dr. Munawir Sjadzali, MA (Jakarta: IPHI dan Paramadina, 1995), 565.
}

to other creatures and assumes that humans are the center of the world's ecosystem. Anthropocentrism is believed to be one of the triggers for environmental damage, therefore the meaning of anthropocentrism found in the verses of the Qur'an must be reinterpreted to shift to ecological-contextual interpretation. The previous study conducted by Muslim scholars discussed the environment as an object of study based on the verses of the Qur'an.

Mujiyono Abdillah in his research gave rise to the concept of Islamic environmental theology as a religious reference with ecological insight. ${ }^{11}$ A.Qadir Gassing discusses environmental problems that produce environmental moral principles based on the Qur'an and hadiths. ${ }^{12}$ Mudhofir offers the concept of hifdul al-bî'ah (protecting the environment) as part of maqâșid al-sharî'ah Mudhofir. Introduced a concept of hifdul al-bî'ah (protecting the environment) as part of maqâșid al-sharî'ah $h^{13}$. Balitbang Departemen Agama Republik Indonesia on Tafsīr al-Qur'an Tematik Pelestarian Lingkungan Hidup. ${ }^{14}$ In his study, Fachruddin Mangunnjaya believed that it was very possible to build environmental awareness in Indonesia through Islamic principles. Given that Indonesia is the largest Muslim community in the world. ${ }^{15}$ Ahmad Saddad, in his writings, tries to create a new paradigm in the study of interpretation called ecological interpretation, which is the

\footnotetext{
${ }^{11}$ Mujiyono Abdillah, Teologi Lingkungan Islam (Disertasi, IAIN Syarif Hidayatullah, Jakarta, 2001). See also, Mujiyono Abdillah, Agama Ramah Lingkungan, Perspektif Al-Qur'an (Jakarta: Paramadina, 2001), 33-51.

${ }^{12}$ A. Qadir Gassing, PerspektifHukum Islam Tentang Lingkungan Hidup (Disertasi, IAIN Syarif Hidayatullah Jakarta, 2001); See also A. Qadir Gassing, "Environmental in Islam, Philosophical, Ethical, and legal-formal Exploration," JISCA 02, no. 01 (June 2013): 13-14.

${ }^{13}$ Mudhofir Abdullah, al-Qur'an dan Konservasi Lingkungan, Argumen Konservasi Lingkungan sebagai Tujuan Tertinggi Syariah (Jakarta: PT Dian Rakyat, 2010), 329-337.

${ }^{14}$ Lajnah Pentashihan Mushaf al-Qur'an Balitbang Depag RI., Tafsīr al-Qur'an Tematik Pelestarian Lingkungan Hidup (Jakarta: Lajnah Pentashihan al-Qur'an, 2009), 20-22.

${ }^{15} \mathrm{M}$. Mangunjaya, "Developing Environmental Awarness and Conservation through Islamic Teaching," Journal of Islamic Studies 22, no. 1 (2011): 37-38. DOI 10.1093/jis/etq067.
} 
effort of a commentator to elaborate on his interpretation from an ecological point of view ${ }^{16}$ but the study of the verses of the Qur'an still refers to the concept of environmental theology that Mujiyono has discussed. Abdul Mustaqim in his writing generally reviewed the idea of ecological interpretation as an effort to establish good communication with nature. The notion of interpretation is directed (alignments) on a proecological perspective. ${ }^{17}$ This study of Mustaqim was further systematized in his writings almu'âmalah ma'a al-bî̀'ah fì mandûri al-Qur'ân al-karîm (dirâsah tafsîr al maudî $\hat{\imath}$-al-siyâqî). ${ }^{18}$

This study examined environmental problems using the perspective of the Qur'an referring to the interpretation of anthropocentric verses in the Qur'an. Thematic methods collect the verses of al-Qur'an mean anthropocentric maudhû' $\hat{\imath}^{19}$ The approach used to analyze was the contextual hermeneutic approach. ${ }^{20}$ This method was able to

\footnotetext{
${ }^{16}$ Ahmad Saddad, "Paradigma Tafsir Ekologi," Jurnal Kontemplasi 05, no. 01 (Agustus 2017): 49-72.

${ }^{17}$ Abdul Mustaqim, Menggagas paradigma tafsir ekologi, http:// iat.uin-suka.ac.id/index.php/page/kolom/detail/2/menggagasparadigma-tafsir-ekologi, accessed on 5 December 2017.

${ }^{18}$ Abdul Mustaqim, "al-mu'âmalah ma'a al-bî'ah fî̀ mandûri alQur'ân al-Karîm” (Dirâsah Tafsîr al Maudû î - al-Siyâqî," Jurnal Essensia 19, no. 1 (April 2018).

${ }^{19}$ Method stages maudhû' $̂$ further see. M. Quraish Shihab, Kaidah Tafsìr. Syarat, Ketentuan, dan Aturan yang Patut Anda Ketahui Dalam Memahami ayat-ayat al-Qur'an (Tanggerang: Lentera Hati, 2013), 389-390.

${ }^{20}$ According to Abdullah Saed Contextual approach is often associated with forms of Islamic reformism compared to textualist approaches, contextual approaches have a more nuanced approach to finding 'meaning' in the Qur'anic text, although the details of this approach will often differ between scientists. The general characteristic of contextual scientists is that they argue the meaning of the Qur'anic verses (or hadiths), to some extent are not static. This means, in this sense, that their meanings evolve over time, and depend on socio-historical, cultural and linguistic contexts. For further text see Abdullah Saed, the Qur'an an Introduction (New York: Routledge, 2008), 220-221.

The stages for contextualization are as follows: (1) Encounter with the world of the text, (2) Critical analysis, (3) Meaning for the first recipients, and (4) Meaning for the present. Further see, Abdullah Saed, Interpreting The Qur'an Towards A Contemporary Approach (London and New York: Routledge, 2006), 150.
}

express the meaning of the content of al-Qur'an as well as the universal message of al-Qur'an so that it can bring up alternative interpretations that can give a new style in the realm of interpretation. The verses considered to have anthropocentrism spirit were examined how the understanding of the interpreter scholars. It was then analyzed in the form of re-interpretation with contextual hermeneutics. The goal was to shift the meaning and spirit of anthropocentrism in these verses. It finally presented a relevant-contextual sense that was an ecological insight interpretation. It is then called an environmental understanding.

\section{Antroposentrisme in al-Qur'an}

According to Sony Keraf, anthropocentrism is a philosophical theory that says moral values and principles only apply to humans. Human needs and interests have the highest and most important value. According to this understanding, ethics only applies to humans. So that demands for moral responsibility and obligation to the environment are considered irrelevant and out of place. ${ }^{21}$ According to Sudharto, anthropocentrism is a paradigm that believes in humans as natural rulers. Nature is valued as an object to meet human needs. As a result of this perspective, environmental disasters have arisen because the carrying capacity and capacity of the environment have been exceeded due to over exploitation. ${ }^{22}$ Meanwhile, Soerjani, as quoted by Rohadi, defined that anthropocentrism is an environmental ethic that places man as the center of the natural system and all of its contents. The values that are considered the highest are humans and their interests. While nature is positioned as a complement and object of meeting human needs so that view is seen as meaningless and worthless. Anthropocentrism ethics refers to shallow ecology because it only looks at human interests

\footnotetext{
${ }^{21}$ Sony Keraf, Etika Lingkungan, 49.

${ }^{22}$ Sudharto P. Hadi, Manusia dan Lingkungan (Semarang: Badan Penerbit Universitas Diponegoto, 2013), 53-54.
} 
and ignores others (nature). ${ }^{23}$ Definition of anthropocentrism in the dictionary of philosophy are: (a) This term refers to the view that humans are the center and final destination of the universe, (b) Humans are central to the functioning of the universe and the universe sustains and in stages supports these values. ${ }^{24}$

Anthropocentrism based costs on the interests and benefits of humans rather than on the importance of profit on nature itself. As a result, environmental problems did not provide direct benefits to humans and not noticed or even marginalized. Mujiyono called this ideology an arrogant and chipped ecology or in humane. This ideology triggers humans to feel as extraordinary beings and considered unimportant or unnoticed to others. ${ }^{25}$

Sony Keraf explicitly accused that Christian theology, western philosophy, the tradition of liberal thought including modern science, and even great thinkers such as Aristotle, Thomas Aquinas, Rene Descartes, and Immanuel Kant were at the root of the emergence of anthropocentrism ethics. The argument from Sony Keraf is as follows: (a) In the book of events, chapters 1, verses 26-28 say that God created man in God's image on the sixth day as the culmination of all his creative works. Furthermore, God gave up the universe and its contents to humans to master and conquer. (b) The Aristotelian tradition as developed by Thomas Aquinas focused on the great chain of being that according to him, life on earth forms a perfect life chain from the simplest to the most accurate, namely God himself. In this chain, humans occupy the closest position to the most excellent. It means that humans occupy the top of the chain of creation so that humans are considered to be superior to all other creations. (c) Humans are considered the highest and most

\footnotetext{
${ }^{23}$ Tasdiyanto Rohadi, Budaya Lingkungan, Akar Masalah dan Solusi Krisis Lingkungan (Yogyakarta: Ecologia Press, 2011), 10-11.

${ }^{24}$ Loren Bagus, Kamus Filsafat, 60.

${ }^{25}$ Mujiyono Abdillah, Agama Ramah Lingkungan, Perspektif AlQur'an, 31.
}

respectable compared to other creatures because humans are the only free and rational beings as understood by Thomas Aquinas, Rene Descartes, and Immanuel Kant. ${ }^{26}$

The accusation from Sony Keraf was in line with Lynn White in his writings, he claimed that Christian theology is the most anthropocentric religion based on Adam's creation mythology. God created the natural world to fulfill his needs even though Adam was part of nature because he was created from clay, but he was not part of life but the image of God. Besides that, there was also a Christian axiom stated that the existence of nature is nothing but to serve human needs. ${ }^{27}$ Then Seyyed Hossein Nasr accused the environmental crisis of being caused by a scientific revolution to gain power in life. It was one of the triggers for the environmental crisis facing modern society today. ${ }^{28}$

On that basis, Lynn White assessed that humans need to find a new religion or try to reinterpret their religious teachings to be appropriate with the ecology. According to him, religion is a means to improve the quality of the environment that is already quite severe. Humans can no longer rely on technology and science to preserve the environment so religion is his hope. ${ }^{29}$ The context of this study was the teachings of Islam contained in al-Qur'an that meaning is potentially anthropocentric.

Referring to the things that give impetus to the anthropocentrism view mentioned above when compared to the meaning of the verses of al-Qur'an, similar verses of al-Qur' an are found to have the same purposes. The results of this study found that verses in the Qur' an normatively have

\footnotetext{
${ }^{26}$ Sony Keraf, Etika Lingkungan, 52-53.

${ }^{27}$ Lynn White, JR. "The Historical Roots of Our Ecological Crisis,"1205 and 1207.

${ }^{28}$ See Seyyed Hossein Nasr, Man and Nature The Spiritual Crisis in Moden Man (Sydney: George Allen and Unwin. Ltd, 1968), 5-7.

${ }^{29}$ Lynn White, JR. "The Historical Roots of Our Ecological Crisis," 1206.
} 
anthropocentric meaning using an index ${ }^{30}$ and $\mathrm{Mu}^{\prime} \mathrm{jam}^{31}$ that classified as follow:

1. Humans as the most glorified creatures are in the surah Q.S. al-Baqarah/2: 34, Q.S. alA'raf/7: 11, Q.S. al-Hijr/15: 28-31, Q.S. alIsraa/17: 70, Q.S. Shaad/38: 71-74 dan Q.S. at-Tîn/95: 4

2. Humans as creatures who have power in nature are found in surah Q.S. al-Baqarah/2: 22 and 29, Q.S. al A'raf/7: 10, Q.S. an-Nahl/16: 14, Q.S. al Haj/22: 65, Q.S.Luqman/31: 20, Q.S. Q.S.Yasin/36: 71-72 Q.S. al-Jatsiyah/45: 1213, Q.S.Ghafir/40: 61 and 64.

3. Humans as Caliphs on Earth are found in the surah Q.S. al-Baqarah/2: 30, Q.S. alAn'am/6: 165, Q.S. al A'raf/7: 69 and 129, Q.S. Yunus/10: 14, Q.S. an-Naml/27: 62, Q.S. Fathir/35: 39 and Q.S. Shaad/38: 26.

The above verse classification rests on the formulation of Lynn White, Sony Keraf, Hossein Nasr, and has been formulated systematically by Mujiyono. Anthropocentrism in Islamic theology, according to him, is rooted in the belief that humans are super beings, humans are natural rulers and human concepts are as Khalifah of the earth. These three basic concepts become obstacles to create an ecological civil society. Therefore, efforts are needed to reconstruct these three concepts called mujiyono with "environmentally sound theology". ${ }^{32}$ However, this study was re-interpreted on the three ideas with a contextual hermeneutic approach that results in an environmental interpretation format.

Humans have a significant role compared to other creatures. Humans are God's highest-created creatures than others. The meaning emerges from

\footnotetext{
${ }^{30}$ Azharuddin Sahil, Indeks al-Qur'an (Bandung: Mizan,1995); Sukmadjaja Asya'rie and Rosy Yusuf, Indeks al-Qur'an (Bandung: Pustaka,1984).

${ }^{31}$ Muhammad Fuad 'abd al-Baqy, al-Mujam al Mufaharas li alfaz al-Qur'an al-Karim (Bairut: Darul Fikr,1994).

${ }^{32}$ Mujioyono Abdillah. Fikih Lingkungan, Panduan Spiritual Hidup Berwawasan Lingkungan (Yogyakarta: Akademi Manajemen Perusahaan YKPN, 2005), 35-36.
}

Q.S. at-Tîn/95: 4 as well as Q.S. al-Baqarah/2: 29 that humans have power and ownership over what Allah has created on earth and Q.S. al-Baqarah/2: 30 is interpreted as a legitimation that humans are God's representatives on earth which are called "caliphs." These meanings have the potential to trigger non-egalitarian views on nature and must, therefore, be interpreted because they can bring the wrong paradigm and will be continually affirmed by the next generation.

From the presentation of Lynn White, Hossen Nasr, Sony Often and also Mujiyono about the triggers behind the idea of anthropocentrism, it did not seem excessive. It canbe concluded that the verses have been mentioned also have anthropocentric nuances. Therefore it is urgent to be reviewed by re-interpreting the contextual hermeneutics approach. The meaning that is believed can be shifted to an ecological-contextual purpose.

\section{Anthroposentric Verse In al-Qur'an}

1. The Concept of Humans as the Most Exalted Beings

Human conceptions as glorified beings compared to others in the Qur'an are found in Q.S.al-Baqarah/2: 34, Q.S. al-A'raf/7: 11, Q.S. al-Hijr/15: 28-31, Q.S. al-Israa/17: 70, Q.S. Shaad/38: 71-74, and Q.S. at-Tîn/95: 4. In this paper, only a few verses were described to represent each category because of the limited pages available. The interpretation is as follows: "And [mention] when We said to the angels,

"Prostrate before Adam"; so they prostrated, except for Iblees. He refused and was arrogant and became of the disbelievers" (Q.S. al-Baqarah/2: 34).

The order of prostration in verse of usjud $\mathrm{u} l i$ Adam (اسـجدو الأدم) literally means higher degrees of humans than angels and demons that these two creatures were ordered to bow down to Adam. According to Muhammad Ibn Mandûr in Lisânul Arab explained that the word of sujûd (سجود) is the root word of sajada-yasjudu-sujûd and (سجد يسجد 
means putting the forehead on the ground. ${ }^{33}$ It literally means the meaning of prostration is to put the forehead on the ground.

Ibnu Katsîr comprehended the verse; the command of prostration is a form of great glory given by Allah SWT to Adam and his descendants. The existence of this prostration was as a form of respect, appreciation, and glorification as the story of the Prophet Joseph is enshrined in Q.S. Yusuf/12: 100:

"And he raised his parents upon the throne, and they bowed to him in prostration."

Furthermore, Ibn Katsîr argued that this was the Shari'a of the previous community (before the Prophet Muhammad SAW). How to glorify human beings with prostrations has been removed in Islam. It was based on the hadith from Muadz talked "I ever came to sham when I arrived there I witnessed them prostrating to their religious leaders and I said" you O Messenger of Allah is more entitled to be a place of prostration then he said:

"No, if I were allowed to order humans to prostrate to someone, then I would ask a wife to bow to her husband because of the greatness of his right." 34

Furthermore, Ali al-Shâbûnî interpreted ay sujûd tahiyah wa ta'zim wa ala sujûd 'ibâdah prostration as a form of greeting and glorifying not prostration in the form of worship. ${ }^{35}$ Sayid Qutub interpreted prostrating you to Adam is a form of high respect for humans even though it is said to be a creature that causes damage and sheds blood on the earth. But because humans are given a secret that can lift their degrees in the form of secular secrets and independent irâdah to choose

\footnotetext{
${ }^{33}$ Muhammad Ibnu Mandûr, Lisânul Arab, Juz. 3 (Beirut: Dâru Shâdr, 1414 H), 204.

${ }^{34}$ Ismâ'̂̂l bin Umar bin Katsîr al-Quraisî, Tafsîr al- Qur'ân al-A'dhîm (t.tp: Dâru Tayyibah li Nasri wa Tauzî', 1999) CDROOM second edition versi 2.11. Software al-Maktabah alSyâmilah, chapter 1, 231-232

${ }^{35}$ Muhammad Ali al-Shâbûnî, Safwatu al-Tafâsîr (BeirutLebanon: Dâru al-Fikr, 1981), 43.
}

their way of life. The existence of various kinds of characters that exist in humans and also the ability to control his irâdah in facing steep paths, and his seriousness in carrying out the mandate of Allah SWT as caliph on earth is the secret behind the respect given to him. ${ }^{36}$

Rasyîd Ridhâ stated in the interpretation of al-Manâ that the word prostration in the above verse was not prostration in the sense of worship but prostration in the spirit of empowerment, submission and struggle. It was a form of respect from previous people to the king or those who are glorified as the prostration of the Prophet Jacob and his children to the Prophet Joseph. Rasyîd Ridhâ classify the type of prostration into two (1) prostration of worship means tiredness to Allah SWT which is obligatory syari' ah for each mukalaf and (2) Prostration to fellow-creatures, prostration of personal will as a form of respect. ${ }^{37}$ In surah at-Tîn/95: 4 stated that Allah has created man in the best of stature.

"We have certainly created man in the best of stature" (at-Tîn/95: 4).

According to at-Thabari interpretation, the word of ahsanu takwîm (in the best of the form) in surah at-Tîn/95: 4 means ahsanu sûrah in the best of stature. According to ahsanu takwim means ahsanu khalqi in the best creatures. ${ }^{38}$ Khâzin interpreted the verse with ahsanu sûrah. Khâzin understood humans are created as the best possible creation because humans are equipped with knowledge, understanding, thoughts and logic that are not given to other creatures. ${ }^{39}$

\footnotetext{
${ }^{36}$ Sayyid Qutub, Fî Dzilâli al-Qur'ân (Beirut-Lebanon: Darussy Syuruq, 1992). CD-ROOM software al-Maktabah al-Syâmilah, versi 3.48.

${ }^{37}$ Muhammad Rasyîd Ridhâ, Tafsîr al-Manâr (Kairo: al-Haiah al-Misriyah al-'Âmah li al-Kitâb, 1990). CD-ROOM software al-Maktabah al-Syâmilah, versi 3.48, chapter 1, 221.

${ }^{38}$ Abû Ja'far al-Tabarî, Jâmi 'ul Bayân fî Ta'îl al-Qur'ân, 2000, CD-ROOM, second edition versi 2.11. Software alMaktabah al-Syâmilah, 507-508

${ }^{39}$ A'laudîn Alî Khâzin, Tafsîral-Khâzinal Musama Lubabu Ta'wîl Fî Ma'anî al-Tanzîl (Bairut-Lebanon: Daru al-Fikr, 1979) CD-ROOM, second edition versi 2.11. Software alMaktabah al-Syâmilah, 266.
} 
Surah at-Tîn/95: 4 implies that Allah SWT has a great concern for humans. The attention appeared from the creation that the composition of the body is valuable compared to other creatures ranging from the physical structure that is accurate and complicated, its intellect is unique, and the formation of its singular spirit, so the interpretation of Sayyid Qutub ${ }^{40}$ to surah at-Tîn/95: 4.

The understanding of the two verses is very anthropocentric because it made human position superior compared to other creatures. The first verse addresses the value of human glory which is more elevated than other creatures by being ordered to prostrate (give respect) to humans, as well as Q.S. at-Tîn/95: 4 which reviews human stature that is perfect and superior than others. This view has the potential to make humans feel incredible and noble so that what arises arrogance in interacting with other creatures instead. This arrogance causes arbitrary behavior in utilizing nature and its contents, ultimately damaging the environment.

\section{The Concept of Man As A Being Who Has Power In Nature}

The concept of man as a natural ruler, in alQur'an can be found in Q.S. al-Baqarah/2: 22 and 29, Q.S. al-A'raf/7: 10, Q.S. an-Nahl/16: 14, Q.S. al Haj/22: 65, Q.S. Luqman/31: 20, Q.S. Q.S.Yasin/36: 71-72, Q.S. al-Jatsiyah/45: 12-13, Q.S.Ghafir/40: 61 and 64. The interpretation is as follows:

\section{"It is He who created for you all of that which is on the earth. Then He directed Himself to the heaven, [His being above all creation], and made them seven heavens, and He is Knowing of all things" (al-Baqarah/2: 29).}

The al-Qur'an editor in verse uses the word خلق لكم ما فى الأرض (khalaka lakum mâ fíal-ard),

${ }^{40}$ Sayyid Qutub, Fî dzilâli al-Qur'ân (Beirut- Lebanon: Darussy Syuruq,1992), CD-ROOM Second Edition 2.11, Software al-Maktabah al-Syâmilah, 61. the word lakum in this verse refers to humans who have been appointed by Allah SWT as khalifah on the earth. Explicitly the meaning of the verse is clear that everything that exists on this earth Allah SWT created for humans. Sayyid Qutub in his interpretation delivered the word "lakum" which means "for you" has a deep and memorable meaning. This word indicates that Allah SWT created a man for something great. Allah SWT created them (humans) to become caliphs on earth. It is stated that humans are people who have and have an influence on everything created by Allah SWT on earth. Even Sayyid Qutub called humans as the highest beings on earth and became the owner of inheritance. ${ }^{41}$

"And We have certainly established you upon the earth and made for you therein ways of livelihood. Little are you gratefull" (Q.S. alA'raf /7: 10).

Allah SWT has placed humans to live on earth. A placeis having wa al- murâd min altamkîn al-tamlî. It means Allah SWT makes the earth a site of human life that can be taken advantage of in it in the form of livelihood for the survival of human life. This livelihood is divided into two: (1) A livelihood that has been blessed by Allah SWT to humans in the form of fruits, plants and various kinds of food and drinks, and (2) Livelihood obtained by humans because of his efforts (work) to gain profits in trading and others. Nevertheless, his efforts were none other than because of the advantages that Allah SWT gave to his servants. For the abundance and the many favors given, humans should be obedient and grateful to Him. Thus the analysis of Khâzin interpretation. ${ }^{42}$

The verse confirms that the earth and its contents are in the interest of humans. The ل (lakum) editor in verse strengthens the

${ }^{41}$ Sayyid Qutub, Fî Dzilâ Li al-Qur'ân, 38

${ }^{42}$ A'laudîn Alî bin Muhammad bin Ibrâhîm (Khâzin), Lubabu Musama Lubabu Ta'wîl Fî Ma'anî Al Tanzîl, Juz. 2 (Bairut: Darul Kitab al- Ilmiyah, 1415 H), 183. 
assumption, so the meaning of the verse is clearly anthropocentric.

"Do they not see that We have created for them from what Our hands have made, grazing livestock, and [then] they are their owners? And We have tamed them for them, so some of them they ride, and some of them they eat (Q.S. Yasin /36: 71-72).

Ibnu Abas interpreted مَلْكُونَ (mâlikûn) in verse with humans as officers who have control over the favors given by Allah SWT. ${ }^{43}$ Ibnu Katsîr understood that Allah SWT says the support that have been given to humans in the form of livestock animals have been subdued for them. Qatadah further explained the purpose of the phrase is to master, to make it subject to humans. These animals are docile, do not fight it, can be ridden for travel, and carry various kinds of luggage to multiple regions. Besides, these animals can also be slaughtered for food. Humans can also benefit from it such as feathers that can be made as household items for human needs. ${ }^{44}$

The above verse confirms that the livestock animals that Allah created are subjected to human interest for consumption and transportation media. This meaning is anthropocentric because the existence of animals becomes the object of complementary human needs and humans have control over it.

\section{The Concept of Man as Khalifah (Caliph on} Earth)

The human concept as khalifah on earth is in Q.S. al-Baqarah/2: 30, Q.S. al-An'am/6: 165, Q.S. al-A'raf/7: 69, 129, Q.S. Yunus/10: 14, Q.S. an-Naml/27: 62, Q.S. Fathir/35: 39 and Q.S. Shaad/38: 26.

And [mention, O Muhammad], when your Lord said to the angels, "Indeed, I will make upon the earth a successive authority." They

\footnotetext{
${ }^{43}$ Abdullâh bin Abâs, Tafsîr Ibnu Abâs, juz 1, 373.

${ }^{44}$ Ismâ'îl bin Umar bin Katsîr al-Quraisî, Tafsîr al- Qur'ân alA'dhîm, juz 6, 592.
}

said, "Will You place upon it one who causes corruption therein and sheds blood, while we declare Your praise and sanctify You? " Allah said, "Indeed, I know that which you do not know" (al-Baqarah/2: 30).

The word of "khaliffah" in verse, according to Quraish Shihab in al-Misbah interpretation, explained that the concept of khaliffah originally had the meaning of replacing or coming after what had happened before. On this basis, some understand the phrase khaliffah, representing Allah SWT in upholding His will ${ }^{45}$ And establishes its provisions but not because Allah is unable or makes humankind as God but because Allah intends to test people and pay their respects. ${ }^{46}$ Quraish Shihab in his other book, described the elements of khalifah in the view of al-Qur'an. According to him, three components that make up the concept of khaliffah are (1) Man himself, (2) The universe, which is mentioned in Q.S. alBaqarah/2: 22, (3) Man's relationship with nature and all its contents, including with humans. ${ }^{47}$

Furthermore, Ali al-Sabuni in his interpretation of Safwatu al-Tafâsîr, explained khalîfah is someone who replaces or replaces one's position. Called khalifah because he replaced Allah in enforcing His will and carrying out his orders. ${ }^{48}$ Allah SWT created khaliffah on the earth so

\footnotetext{
${ }^{45}$ According to Tafsîr al-Manâr the will of Allah SWT there are two kinds; (1) The will of Allah SWT is based on the law of kasuality (sunnatullâh) which applies universally to all beings, and (2) The Absolute Will of Allah is the will of Allah who is the full authority of Allah SWT without being based on the law of causality [Muhammad Rashîd Ridhâ, Tafsîr al-Manâr (al-Haiah al-Misriyah: t.p. 1990), section 1, 206].

${ }^{46}$ M. Quraish Shihab, Tafsir al Misbah Pesan, Kesan dan Keserasian Al-Qur'an, Vol. I (Jakarta: Lentera Hati, 2000), 142. ${ }^{47} \mathrm{M}$. Quraish Shihab, Membumikan al-Qur'an (Bandung: Mizan,1992), 29.

${ }^{48}$ There are two types of Allah's commands, namely: (1) The order of takwini, namely the order of Allah's creation in his creatures that cannot be denied such as the creation of the earth and sky, (2) The order of tasyrî'i i.e. the command of Allah SWT sent down to humans through Prophets and Apostles to convey to Humans. This command can be carried out by humans or reject it such as there is no compulsion in choosing Islam as a religion (Q.S. al-Baqarah/2: 256) or freedom to believe or disbelieve (Q.S. al-Kahfi/18: 29).
} 
that Adam or some people became khalifah for some others from time to time and generation to generation. ${ }^{49}$

Moreover, Sayyid Qutub gave a slightly different interpretation that Allah SWT wants to surrender control of the earth to new creatures (humans). It is an excellent task that Allah SWT surrenders to him. Allah SWT has given a lot of potential to this new creature (man) and has given him plenty of adequate preparation to realize the divine will. It is a high position (khalîfah) for humans at the level of nature to exist on earth and this is the glory desired by Allah SWT for humans. ${ }^{50}$

The interpretation of the verses above proved that humans have a significant role compared to other creatures. The meaning of this interpretation is very anthropocentric. Humans are beings whose degrees are elevated by Allah SWT are created with the best form than other creatures. The meaning emerges from Q.S.at-Tîn/95: 4 as well as Q.S. al-Baqarah/2: 29 that humans have power and ownership over what Allah has created on earth. Q.S. al-Baqarah/2: 30 interpreted as social legitimation is God's representative on earth which is called "khalifah." These meanings can trigger non-egalitarian views on nature. Therefore, it must be reinterpreted so it is not to lead the wrong paradigm and continue to be affirmed by the next generation.

\section{Hermeneutic Analysis of the Interpretation of Anthropocentric Verses}

1. Hermeneutic Analysis of the Interpretation of Human Signs as the most glorified being

The first stage is an encounter with the world of the text. The verses of humans as the most glorified human beings are contained in Q.S. al-Baqarah/2: 34, Q.S. al-A'raf/7: 11, Q.S. al-Hijr/15: 28-31, Q.S. al-Israa/17: 70, Q.S. Shaad/38: 71-74 and Q.S. at-Tîn/95: 4.

\footnotetext{
${ }^{49}$ Muhammad Ali al-Șâbûnî, Șafwatu al-Tafâsîr (BeirutLebanon: Dâru al-Fikr, 1981), 48-49.

${ }^{50}$ Sayyid Qutub, Fî Dzilâli al-Qur'ân, 28.
}

The second stage is critical analysis by searching for the meaning of the verses without relating them to the original or present purpose. At this stage, linguistic analysis is carried out by borrowing Arabic dictionary tools such as $I b n$ Mandûr with Lisânul Arab, Mu'jam Maqâyîs alLughoh work of Ahmad bin Fâris.

Conception of prostration that is in Q.S. al-Baqarah/2: 34, Q.S. al-A'raf/7: 11, Q.S. al-Hijr/15: 28-31 and Q.S. Shaad/38: 71-74 according to Lisânul Arab explained that the word of sujûd is the root word of sajada - yasjudu - sujûdan means putting the forehead on the ground. ${ }^{51}$ The meaning of prostration literally is to put the forehead on the ground.

Third Stage Meaning for the first recipients. The interpretation of the verses on the conception of prostration in Adam is interpreted in the sense of paying homage or greeting sujûd tahiyah wa takrimah to a creature whose name is Adam which is then referred to as the father of men as the explanation of the interpretation described in the previous chapter.

The fourth stage is meaning for the present. The prostrations are narrative verses, which are stories and do not have the legal dimension or the provisions regarding lawful and illegitimate. Abdullah Saed returns to its literal meaning related to the context. However, the researcher tried to uncover the meaning of the present in the ecological context.

The conception of prostration means behavioral reverence is no longer valid for the people of Muhammad. It was confirmed in the interpretation of Ibn Katsîr that explained that the way to glorify people with prostration has been removed in Islam. It can be a way of respecting or worshiping human beings in today's context by giving respect, shaking hands, bowing to the body and other forms that are accepted by the public and no longer by prostrating. Nevertheless, the value of the conception of prostration as a

\footnotetext{
${ }^{51}$ Muhammad Ibnu Mandûr, Lisânul Arab, Juz 3 (Beirut : Dâru Shâdr, 1414 H), 204.
} 
sign of respect and glory to humans still exists. The granting of glory to humans is a consequence of human responsibility as a caliph on earth. Although it is the potential to make humans arrogant and feel superior to other creatures. It is one of the triggers of behavior that is not impartial to nature that ultimately makes nature as an object of meeting human needs. Therefore the glory given by Allah SWT to humans is accompanied by the command to not cause damage on earth (Q.S. al-Baqarah/2: 11,12, 27, 60 and 205 Q.S. al-Maidah/5: 64, Q.S. al-Araaf/7: 56 Q.S. asy-Syuaraa/26: 152). As an elevated creature he must be able to do good and ihsan for all beings created by Allah SWT (Q.S. an-Nahl/16: 90).

Then the words ahsan and taqwîm in surah at-Tîn/95: 4 the literal meaning is proper ${ }^{52}$ while the word qawâm means good stature. The original meaning of the verse is based on the interpretations of the commentators mentioned earlier: humans are created with the best stature because humans are equipped with knowledge, understanding, thoughts and logic that are not given to other creatures. This meaning does not have an environmental vision because of it superiors humans to others.

The contextual meaning or present meaning in an environmental perspective is the word ahsanu taqwim that is interpreted as well as the stature. The term does not change the meaning; it is only the development of understanding in two words-human being glorified because of his intellect and created with the best possible character. But this glory must be accompanied by not being arrogant (Q.S. anNisa'/4: 36, Q.S. an-Nahl/16: 23, Q.S. al-Isra/17: 37) feeling superior compared to other creatures, because of arrogant prohibited by Islamic teachings. As a creature elevated degree, he must be able to do good and ihsan in all beings created by Allah SWT (Q.S. an-Nahl/16: 90) so that life goes well. Therefore, the advantages given to humans must be used as a tool to care for the earth, to the sake of the preservation and sustainability of life. Humans, even though they are called perfect beings, still need to be supported by the existence of other creatures, like plants, water, air, animals, and so on, because humans cannot live alone. The analysis of the interpretation of human verses as the most glorified being:

Table 1 The Contextual Meaning of Prostration Concept

\begin{tabular}{|c|c|c|c|}
\hline Stage 1 & Stage 2 & Stage 3 & Stage 4 \\
\hline $\begin{array}{l}\text { Prostration in (Q.S. } \\
\text { al-Baqarah/2: 34, Q.S. } \\
\text { al-A'raf/7: 11, Q.S. } \\
\text { al-Hijr/15: 28-31 and } \\
\text { (Q.S. Shaad/38: 71-74 }\end{array}$ & $\begin{array}{l}\text { The word of سجود is the } \\
\text { root word of سجد سجودا means putting the } \\
\text { forehead on the ground } \\
\text { وضع جبهنه بالأرض }\end{array}$ & 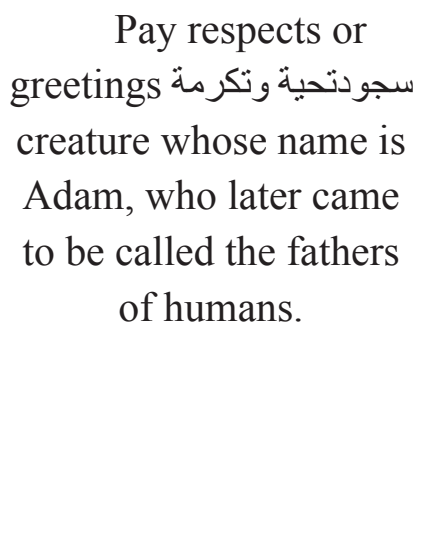 & $\begin{array}{l}\text { The glory to } \\
\text { humans must also be } \\
\text { accompanied by an } \\
\text { understanding of the } \\
\text { command not to cause } \\
\text { damage on earth and } \\
\text { the demands of ihsân } \\
\text { doing good for all } \\
\text { creatures created by } \\
\text { Allah SWT }\end{array}$ \\
\hline
\end{tabular}

\footnotetext{
${ }^{52}$ Ahmad bin Fâris, Mu'jam Maqâyîs al-Lughoh, chapter 2 (Kairo: Dârul Fikr, 1979), 57.
} 
Table 2 Contextual Meanings Of Words Ahsanu Taqwîm

\begin{tabular}{|c|c|c|c|}
\hline Stage 1 & Stage 2 & Stage 3 & Stage 4 \\
\hline $\begin{array}{l}\text { The word of تفن in Surah } \\
\text { and تفويم : } 4 \\
\text { at-Tîn/95 }\end{array}$ & $\begin{array}{l}\text { The meaning of } \\
\text { حسن is right, and } \\
\text { فو ام means good } \\
\text { stature. }\end{array}$ & $\begin{array}{l}\text { The original meaning } \\
\text { is that humans were } \\
\text { created with the } \\
\text { best formö أحسن صور because humans are } \\
\text { adorned with science, } \\
\text { understanding, thoughts } \\
\text { and logic that are not } \\
\text { given to other beings }\end{array}$ & $\begin{array}{l}\text { As a creature that has elevated } \\
\text { human degrees, they must be } \\
\text { able to do good and good for } \\
\text { all creatures created by Allah } \\
\text { SWT so that the life cycle can } \\
\text { run well. Besides that humans } \\
\text { are also ordered not to be } \\
\text { arrogant with other creatures. } \\
\text { As a creature that has elevated } \\
\text { human degrees, they must be } \\
\text { able to do good and ihsân for all } \\
\text { creatures created by Allah SWT } \\
\text { so that the life cycle can run } \\
\text { well. Besides that humans are } \\
\text { also ordered not to be arrogant } \\
\text { with other creatures. }\end{array}$ \\
\hline
\end{tabular}

2. Hermeneutic Analysis Interpretation of the Verses of Humans as Creatures Having Power in Nature

In the first stage is the encounter with the world of the text; verses of humans as creatures have power in nature are Q.S. al-Baqarah/2: 22 and 29, Q.S. al-A'raf/7: 10, Q.S. an-Nahl/16: 14, Q.S. al-Haj/22: 65, Q.S. Luqman/31: 20, Q.S. Q.S. Yasin/36: 71-72, Q.S. al-Jatsiyah/45: 12-13, Q.S. Ghafir/40: 61 and 64.

The second stage is critical analysis by searching for the meaning of the verses without relating them to the original or present purpose. The word of mâlikûn is the root word of malaka according to Maqâyîs al-Lughoh, it is quwat fî al-Sya'i mean something strong ${ }^{53}$

The third stage is meaning for the first recipients. Ibnu Abas interpreted mâlikûn humans as officers who have control over the favors given by Allah SWT. ${ }^{54}$ Ibn Katsîr also gave a similar

\footnotetext{
${ }^{53}$ Ahmad bin Fâris, Mu'jam Maqâyîs al-Lughoh, juz 5, 351

${ }^{54}$ Abdullâh bin Abâs, Tafsîr Ibnu Abâs, juz 1, 373.
}

meaning as a ruler or subject to humans..$^{55}$

The fourth stage is meaning for the present. The word of mâlikûn interpreted as a ruler or controller; in an ecological context it is defined as the use of which is based on balance and responsibility. It is in line with the spirit of al-Qur'an, demanding humans not to waste (arbitrary) and do something balanced equilibrium. ${ }^{56}$ Humans are asked to do good to all beings (Q.S. al-Imran/3: 104) both biotic to maintain the sustainability of the world's ecosystems.

The conception that humans have control over nature was also confirmed by the Prophet Muhammad SAW by saying that Allah has given

\footnotetext{
${ }^{55}$ Ismâ'îl bin Umar bin Katsîr al-Quraisî, Tafsîr al- Qur'ân alA'dhîm, juz 6, 592.

${ }^{56}$ Equilibrium balance is the key to protecting nature. Allah SWT himself created his creation with the appropriate size or measure (al-Qamar/54: 49) the principle of equilibrium must be understood in all aspects of life. That way life will go in harmony and harmony. For more, see Riham R. Rizk, "Islamic Environmental Ethics," Journal of Islamic Accounting and Business Research 5, no. 2 (2014): 196. DOI10.1108/JIABR-09-2012-0060.
} 
this world SAW to humans. However the Prophet warned that this mastery is a test to humans.

"From the Prophet sallallaahu 'alaihi wasallam said: "Verily the world is Kind. And surely Allah has empowered you all. Then Allah waits (pays attention to) what you are doing (in that world). Therefore fear the world and fear women, because the source of the Bani Isarail disaster was a woman" (Muslim book: 4945).

On another hadith, the Prophet Muhammad also reminded that the blessings and prosperity of this world which he called the world's jewelry, could potentially humiliate humans. Therefore humans must be able to manage the "mandate" of world domination wisely and well (Muslim Book: 1743).

For this blessing given to humans in the form of the world and its contents are the mercy given by Allah SWT so that humans are ordered to force Allah SWT and not associate him with it (Q.S. al-Baqarah/2: 22). So the essence of all this is a command to force Allah SWT, as the creator of God who is obliged to be worshiped.

"From 'Abdullah said, "I once asked the Prophet Shallahu'alaijiwasallam, what is the greatest sin in the sight of Allah?" The Prophet replied, "You made a match for Allah, even though He created you" (Bukhari: 6966) see also (Muslim book: 124).

So the meaning of the verses above is the conception that the whole nature is intended for humans, but for this gift, humans are ordered to force Allah SWT and also utilize the gift wisely and responsibly. Hermeneutic analysis of the interpretation of human verses as natural rulers:

Table 3 Contextual Meaning On The Word Of Mâlikûn

\begin{tabular}{|c|c|c|c|}
\hline Stage 1 & Stage 2 & Stage 3 & Stage 4 \\
\hline 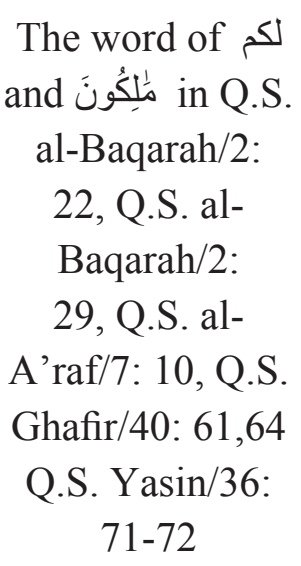 & 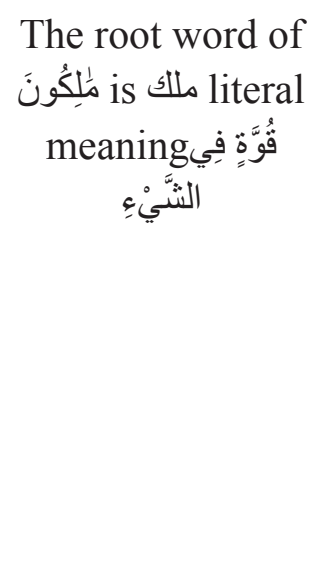 & $\begin{array}{l}\text { meaning humans as } \\
\text { officers have control } \\
\text { over the favors given } \\
\text { by Allah SWT }\end{array}$ & $\begin{array}{l}\text { The term of malaka in the } \\
\text { ecological context is defined } \\
\text { as the use of balance and } \\
\text { responsibility based. It is } \\
\text { appropriate with the spirit of } \\
\text { the al-Qur'an demands humans } \\
\text { not to waste (arbitrary) and do } \\
\text { something balance equilibrium }\end{array}$ \\
\hline $\begin{array}{l}\text { The first stage } \\
\text { of the text. The } v \\
\text { caliphs on the ea } \\
\text { An'am/6: } 165 \text {, al } \\
\text { an-Nam1/27: } 62, \mathrm{~F} \\
\text { The second }\end{array}$ & $\begin{array}{l}\text { Encounter with } \\
\text { es explained man } \\
\text { al-Baqarah/2: } 30 \text {, } \\
\text { raf/7: } 10 \text {, Yunu } \\
\text { ir/35: } 39 \text { and Shac } \\
\text { e is critical anc }\end{array}$ & \multicolumn{2}{|c|}{$\begin{array}{l}\text { relating them to their original or present meaning. } \\
\text { At this stage, the linguistic analysis was conducted. } \\
\text { Ibn Mandûr interpreted the caliph as someone } \\
\text { who replaced the others who were after. Besides, } \\
\text { the caliph can have the meaning of a great sultan } \\
\text { (leader/king). While Ahmad bin Fâris explained } \\
\text { that the caliph came from the word khalifah where } \\
\text { the word has three meanings; (1) The arrival } \\
\text { of something after something and occupy its } \\
\text { position, (2) Different from the beginning, and }\end{array}$} \\
\hline
\end{tabular}




\section{(3) Changed..$^{57}$}

The third stage is Meaning for the first recipients, al-Sâabunî interpreted a caliph is a person who replaces or replaces one's position. It is called the caliph because he replaced Allah in enforcing his will and carrying out his orders. ${ }^{58}$ Sayyid Qutub understands that Allah SWT wants to surrender control of the earth to new creatures (humans), and this is a great task that Allah SWT surrenders to him. Allah SWT has given a lot of potential to this new creature (man) and has given him plenty of adequate preparation to realize the divine will. This is a high position (khalifah) for humans in the level of nature of existence on earth and this is the glory desired by Allah SWT for humans. ${ }^{59}$

The fourth stage is for the present; the word khaliffah in an ecological perspective is interpreted as a prosperous or guardian of being a human being who is an earth-prosperous person. This is in harmony with the spirit of the Qur'an in the QS. Hûd/11: 61. One of the efforts to prosper the earth is to plant trees because trees have an ecological function to support ecosystems on earth. Even explicitly, the Prophet Muhammad also forbade cutting down trees carelessly. ${ }^{60}$ This command contained a vision of a progressive environment. It was reinforced by Abu Bakr's order to Yazid bin Abu Sufyan when he wanted to go to Sham, which was a prohibition to cut trees that were bearing fruit, must not slaughter goats or camels except for food. ${ }^{61}$ Therefore, the word of khaliffah was not interpreted as a ruler or owner but is a guardian that is maintaining the sustainability of the world ecosystem from various forms of damage. The summary analysis of hermeneutics on the interpretation of the verses of Man as Caliph on Earth:

Table 4 The Contextual Meaning Of The Word Caliph (Researcher Analysis)

\begin{tabular}{|c|c|c|c|}
\hline Stage 1 & Stage 2 & Stage 3 & Stage 4 \\
\hline $\begin{array}{l}\text { The word of } \\
\text { Tَin in Q.S. } \\
\text { al-Baqaarah/2: 30, } \\
\text { Q.S. al-An'am/6: } \\
\text { 165, al-A'raf/7: } \\
\text { 10, Yunus/10: } \\
\text { 14, an-Nam1/27: } \\
\text { 62, Fathir/35: } 39 \\
\text { and Shaad/38: } \\
\text { 26. }\end{array}$ & $\begin{array}{l}\text { خَل derived } \\
\text { from the word } \\
\text { خلف has three } \\
\text { meanings; (1) } \\
\text { The arrival of } \\
\text { something after } \\
\text { something and } \\
\text { occupy its position } \\
\text { (2) Different from } \\
\text { the initial (3) } \\
\text { Change }\end{array}$ & $\begin{array}{l}\text { Khaliffah is a person } \\
\text { who replaces or } \\
\text { replaces one's position. } \\
\text { Called the caliph } \\
\text { because he replaced } \\
\text { Allah in enforcing his } \\
\text { will and carrying out } \\
\text { his orders (the caliph } \\
\text { is a representative of } \\
\text { Allah SWT) }\end{array}$ & 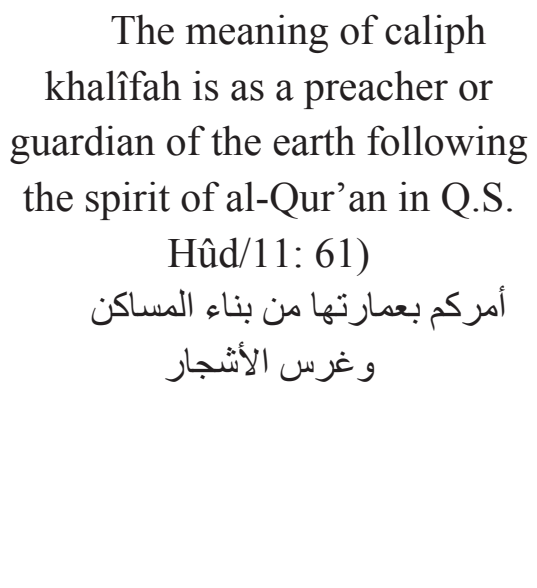 \\
\hline
\end{tabular}

\footnotetext{
${ }^{57}$ Ahmad bin Fâris, Mu'jam Maqâyîsal-Lughoh, chapter 2 (Kairo: Dârul Fikr, 1979), 2010.

${ }^{58}$ Muhammad Ali al-Shâbûnî, Șafwatu al-Tafâsîr, 48-49.

${ }^{59}$ Sayyid Qutub, Fî̀ Dzilâli al-Qur'ân, 28.

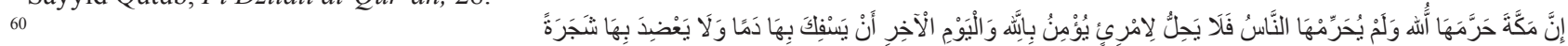
"Allah has made Mecca a haram, but people have not forbidden it. Then it is no longer allowed for a person who believes in Allah and the hereafter to shed blood in it and cut down its trees" (Muslim book, 2413).

610

"Indeed I will testify to you with ten things: do not ever kill women, children and old people. Do not cut the tree that is bearing fruit, do not knock down buildings, do not slaughter goats or camels except for food, do not burn palm trees or sink them. And don't do ghulul or be a coward" (Malik Book, 858).
} 
of interpretation or understanding of al-Qur'an verses lead to the preservation and security of the environment as part of the interpretation of the environment. Otherwise, the results of interpretations that are meaningfully contrary to environmental values or principles are not part of the understanding of the environment. The laws of ecological benefits that have been formulated by environmental thinkers or activists are as follows:

Mujiyono formulated the principles of the environment in his research; (1) Humans as environmental managers, (2) humans as environmental protectors, and (3) Humans are protectors and buffer ecosystems. ${ }^{64}$ According to Qadir Gassing; (1) The principle of ownership. That all the universe and its contents belong to Allah SWT must be protected, (2) the principle of istikhlaf that humans are bathed in managing the earth rather than damaging or exploiting the earth, (3) the principle of wasteful prohibitions, wasteful attitudes must be avoided, (4) The principle of responsibility for the environment, given the environmental damage caused by human activity, then humans are also obliged to improve the environment, (5) the principle al-adlu wa ihsân, the treatment to do justice is not limited to fellow human beings but also to do justice to the environment in its entirety, and (6) the principle of harmony. That humans must be compassionate not only with humans but also with animals, plants and other components of organisms both biotic and abiotic. ${ }^{65}$ Then Sony Keraf with its principle; (1) Respect for nature, (2) Principle of responsibility, (3) The principle of compassion and care, (4) The principle of no harm, (50 The principle of living simply and in harmony with nature, (6) The principle of justice, (7) Principles of democracy, and (8) Principles of moral integrity. ${ }^{66}$ Then other principles formulated

\footnotetext{
${ }^{64}$ Mujiyono Abdillah, Agama Ramah Lingkungan, 201-220.

${ }^{65}$ Qadir Gassing, "Environmental in Islam, Philosophical, Ethical, and legal - formal Exploration," JISCA 02, no. 01 (June 2013) 12-31.

${ }^{66}$ Sony Keraf, Etika Lingkungan, 166-184.
}

by Ibrahim A. Matin include; (1) Maintaining the message of Allah SWT that Man is the protector of the earth, (2) Doing justice to all of Allah's creation, and (3) Living in balance with nature. ${ }^{67}$

Environmental principles are benchmarks for assessing and evaluating a product of interpretation, whether ecological or not. For this reason, understanding the principles and basis of the environment is essential because its role is the determinant of whether a product of interpretation is following environmental values or vice versa. Environmental interpretation products have a dimension of prevention and saving the environment at the same time. Whereas the substantive importance of the environment in the Qur'an is formulated into a product of applicable interpretations so that the values of the Qur'an truly become the spirit in efforts to preserve environmental conservation.

\section{Conclusion}

Anthropocentric verses in the Qur'an are verses that have the meaning of humans as the center of the universe or humans as super-beings compared to other creatures. The categorization is (1) Humans as the most glorified creatures, (2) Humans as creatures who have power in nature, and (3) Humans as Caliphs on Earth. The concept of the human being as the most honored creature is interpreted as a gift from Allah SWT which is then given the mandate to preserve and preserve the earth in its way by not destroying it and keeping the ecosystem in it. The concept of man as the ruler of nature is interpreted to utilize kind fairly and balanced. While the meaning of the caliph does not mean a representative of God but as the guardian or prosperity of the earth. The environmental interpretation is a contemporary interpretation of environmental insight that contains the spirit of the meaning of ecological protection fairly, ihsân and balance. The results

${ }^{67}$ Ibrahim Abdul Matin, Green Deen What Islam Teaches About Protecting the Eart (California: Berret-Koehler Publisher Inc, 2010), 5. 
of the analysis or understanding of the verses of the Qur'an led to the preservation and protection of the environment as part of the interpretation of the environment. Otherwise, the results of arguments that are meaningfully contrary to environmental values or principles are not part of the interpretation of the environment.

\section{References}

Abdillah, Mujiyono. Agama Ramah Lingkungan, Perspektif Al-Qur'an. Jakarta: Paramadina, 2001.

------. Fikih Lingkungan, Panduan Spiritual Hidup Berwawasan Lingkungan. Yogyakarta: YKPN, 2005.

-. Teologi Lingkungan Islam. Disertasi. IAIN Syarif Hidayatullah, Jakarta, 2001.

Abdullah, Mudhofir. Al-Qur'an dan Konservasi Lingkungan, Argumen Konservasi Lingkungan sebagai Tujuan Tertinggi Syariah. Jakarta : PT Dian Rakyat, 2010.

-------. “Green Vison dalam Tradisi Kearifan Syariah Islam." Ibda: Jurnal Kebudayaan Islam 10, no. 1 (January-June 2012).

Abu Daud, Sulaiman bin Daud bin Jarud. Musnad Abu Daud al-Tayalisi. Mesir: Dâr Hajr, 1999.

Asya'rie, Sukmadjaja and Rosy Yusuf. Indeks al-Qur'an. Bandung: Pustaka,1984.

Bagus, Loren. Kamus Filsafat. Jakarta: Gramedia Pustaka Utama, 2002.

al-Baqy, Muhammad Fuad 'Abd. al-Mujam al Mufaharas li Alfaz al-Qur'an al-Karim. Beirut: Darul Fikr, 1994.

Fâris, Ahmad bin. Mu'jam Maqâŷ̂s al-Lughoh. Kairo: Dârul Fikr, 1979.

Gassing, A. Qadir. Perspektif Hukum Islam Tentang Lingkungan Hidup. Disertasi.
IAIN Syarif Hidayatullah Jakarta, 2001.

-------. "Environmental in Islam, Philosophical, Ethical, and legal - formal Exploration." JISCA 02, no. 01 (June 2013).

Hadi, Sudharto P. Manusia dan Lingkungan. Semarang: Badan Penerbit Universitas Diponegoro, 2013.

al-Hasan, Muhammad Ali. al-Manâr fî 'Ulûm Qur'ân. Beirut: Muasash al-Risâlah, 2000.

Health Organization, World. 9 out of 10 People Worldwide Breath Polluted Air. https:// www.who.int/news-room/detail/02-052018-9-out-of-10-people-worldwidebreathe-polluted-air-but-more-countriesare-taking-action. accessed on 20 March 2019.

Ibnu Mandûr, Muhammad. Lisânul Arab. Beirut: Dâr Shâdr, 1414 H.

Jamil, Muhammad Assayed. A Study on Environmental Issue with Reference to the Qur'an and the Sunna. Translated by Lachen Haddad. Kingdom of Morocco: Imprimerie al-Ma'arif al-Jadida Rabat,1999.

JR, Lynn White. "The Historical Roots of our Ecological Crisis. Science." New Series 155, no. 3767 (Mach 1967).

Keraf, A. Sony. Etika Lingkungan Hidup. Jakarta: Kompas, 2010.

Khâzin, A'laudîn Alî. Tafsîr al-Khâzin alMusama Lubabu Musama Lubabu Ta'wîl Fî̀ Ma'anî al-Tanzîl. Beirut-Lebanon: Daru al-Fikr, 1979. CD-ROOM edisi kedua versi 2.11. Software al-Maktabah al-Syamilah.

Lajnah Pentashihan Mushaf al-Qur'an Balitbang Depag RI. Tafsīr al-Qur'an Tematik Pelestarian Lingkungan Hidup. Jakarta: Lajnah Pentashihan al-Qur'an, 2009.

al-Mahali, Jalâl al-Dîn and Jalâl al-Dîn al-Suyûtî. 
Tafsîr al-Jalâlayn. Kairo: Dârul hadîts, n.d.

Malik, bin Anas. Muwatak al-Imam Malik. Beirut: Darul Ihya al-Turats al-Arabi, 1985.

Mangunjaya, M. "Developing Environmental Awarness and Conservation through Islamic Teaching." Journal of Islamic Studies 22, no. 1 (2011). DOI 10.1093/ jis/etq067.

Matin, Ibrahim Abdul. Green Deen What Islam Teaches About Protecting the Eart. California: Berret-Koehler Publisher Inc, 2010 .

Mustaqim, Abdul. Menggagas Paradigma Tafsir Ekologi. http://iat.uin-suka.ac.id/index. $\mathrm{php} / \mathrm{page} / \mathrm{kolom} /$ detail/2/menggagasparadigma-tafsir-ekologi. accessed on 5 December 2017.

' “al-Muâmalah ma'a al-Bî’ah Fî Mandûri al-Qur'ân al-Karîm (Dirâsah Tafsîr alMaudûî al-Siyâqî)". Jurnal Essensia 19, no. 1 (April 2018).

Nasr, Seyyed Hossein. Man and Nature The Spiritual Crisis in Modern Man. Sydney: George Allen and Unwin Ltd, 1968.

al-Nasyâibûri, Muslim bin al-Hujâj Abû Hasan al-Qusyairî. Șahîh Muslim. Beirût: Dârul Ihyâ al-Turâts al-Arabî, n.d.

al-Qazuwainî, Ibnu Mâjah Abû Abdullâh Muhammad bin Yazîd. Sunan Ibnu Mâjah. t.tp: Dârul Ihyâ al-Kutub al-Arabiyah, n.d.

Quddus, Abdul. "Ecotheology Islam: Teologi Konstruktif Atasi Krisis Lingkungan." Ulumuna: Jurnal Studi Keislaman 16, no. 2 (December 2012).

al-Quraisî, Ismâ'̂̂l bin Umar bin Katsîr. Tafsîr al Qur'ân al-A'dhîm.t.tp.: Dâru Tayyibah li Nasri wa Tauzî', 1999. CD-ROOM edisi kedua versi 2.11. Software al-Maktabah
al-Syâmilah.

Qutub, Sayyid. Fî Dzilâli al-Qur'ân. BeirutLebanon: Darussy Syuruq, 1992. CDROOM edisi kedua versi 2.11, Software al-Maktabah al-Syâmilah.

R. Rizk, Riham. "Islamic Environmental Ethics." Journal of Islamic Accounting and Business Research 5, no. 2 (2014): 196. DOI: $10.1108 / J I A B R-09-2012-0060$.

Rasyîd Ridhâ, Muhammad. Tafsîr al- Manâr. Kairo: al-Haiah al-Misriyah al-'Âmah li al-Kitâb, 1990. CD-ROOM Software alMaktabah al-Syâmilah, versi 3.48.

al-Râzi, Fakhrudîn. Mafâtîhul Ghaib: Tafsîr al-Kabîr. Beirut: Dâr Ihyâ' Turâts alArabî, 1420 H.

Rohadi, Tasdiyanto. Budaya Lingkungan, Akar Masalah dan Solusi Krisis Lingkungan. Yogyakarta: Ecologia Press, 2011.

al-Ṣâbûnî, Muhammad Ali. Șafwatu al-Tafâsîr. Beirut-Lebanon: Dâru al-Fikr, 1981.

Saddad, Ahmad, "Paradigma Tafsir Ekologi". Jurnal Kontemplasi 05, no. 01 (Agustus 2017).

Saed, Abdullah. Interpreting the Qur'an Towards Contemporary Approach. London and New York: Routledge Taylor \& Francis Group, 2005.

-------. the Qur'an an Introduction. New York: Routledge, 2008.

Sahil, Azharuddin. Indeks al-Qur'an. Bandung: Mizan,1995.

Saged, Ali Gobaili, et.al. "The Role of Maqasid al-Sharif in Preserving The Environment." Humanomics 33, no. 2 (2017): 301. DOI :10.1108/H-12-2016-0105.

Shihab, M. Quraish. Kaidah Tafsir. Syarat, Ketentuan, dan Aturan yang Patut anda Ketahui dalam Memahami Ayat-Ayat al- 
Qur'an. Tangerang: Lentera Hati, 2013.

------. Membumikan al-Qur'an. Bandung: Mizan,1992.

Tafsir al Misbah Pesan, Kesan dan Keserasian Al-Qur'an. Vol. II. Jakarta: Lentera Hati, 2003.

-------. Wawasan Al-Qur'an Tafsir Maudhui Atas Pelbagai Persoalan Umat. Bandung: Mizan, 1996.

Sidîq Khân, Abû al-Tayyib Muhammad. Fathul Bayân fì Maqâsid al-Qur'ân. Abdullah bin Ibrahim (ed). Beirut: Maktabah 'Asriyah, 1992.

Suwito, NS. Eko-Sufism Konsep, Strategi, dan Dampak. Yogyakarta: STAIN Press
Purwokerto bekerjasama dengan Buku Litera, 2011.

al-Tabarî, Abû Ja'far. Jâmi'ul Bayân Fî Ta'wîl al-Qur'ân. CD-ROOM edisi kedua versi 2.11. Software al-Maktabah al-Syamilah.

Tanja, Victor I. "Agama dan Permasalahan Lingkungan." In Sulastomo et.al. Kontekstualisasi Ajaran Islam 70 Tahun Prof. Dr. Munawir Sjadzali, MA. Jakarta: IPHI dan Paramadina, 1995.

Yale News. Due to Humans, Extintion risk for 1,700 animal species to increseangly by 2070. https://news.yale.edu/2019/03/04/ due-humans-extinction-risk-1700-animalspecies-increase-2070. accessed on 20 March 2019. 